\title{
Community and Writing towards Professional Capital: The Case of Reflective Lesson Study in the Philippine
}

\author{
Pauline Anne Therese Mangulabnan \\ University of Fukui, Japan
}

\begin{abstract}
Professional capital is a function of one's human, social and decisional capital. Under the framework of the Philippine Professional Standards of Teachers (PPST), professional Filipino teachers are agents of students, community and one's learning. In Japan, lesson study is a collaborative in-school professional development that supports teacher growth in the practice. This phenomenological case study examined how the one-year adaptation of Japanese lesson study, with an emphasis on writing and co-reflection, has impacted the professional capital of three Filipino teachers. How can writing contribute to a teacher's professional capital? What themes will teachers write? The researcher took an ethnographic approach in collecting data including classroom observation notes, transcription of teacher discussions and produced reflective practice records. This study narrates the experiences of teachers in writing and co-inquiry. Through writing, teachers were able to record their strengths and weaknesses in content, narrating student-focused learning, and curriculum assessment. Teachers had narrated how the co-inquiry and co-reflection stimulated a closer assessment of their own classroom practices which led to a deeper understanding of students and learning design. They had also elaborated on their decision-making process. The dialogue situated in the reflective lesson study to and fro writing deepened teachers' professional capital.
\end{abstract}

Keywords: teacher writing, reflective lesson study, teacher community, co-inquiry, teacher experiences. 